\title{
DIFFERENTIATION OF AUTONOMIC NEURON PRECURSORS IN VITRO: CHOLINERGIC AND ADRENERGIC TRAITS IN CULTURED NEURAL CREST CELLS ${ }^{1}$
}

\author{
M. FAUQUET, J. SMITH, C. ZILLER, AND N. M. LE DOUARIN'
}

Institut d'Embryologie du Centre National de la Recherche Scientifique et du Collège de France, 94130 Nogent-sur-Marne, France

\begin{abstract}
The development of autonomic neuronal precursors was studied in cultures of microsurgically excised quail neural crest grown alone and associated with other young embryonic tissues. Biochemical differentiation in the cultures was followed by measuring their ability to synthesize acetylcholine (ACh) and catecholamines (CA) from radioactive precursors; cytochemical aspects of their differentiation were examined by techniques including electron microscopy, cholinesterase histochemistry, and CA cytofluorescence.

Mesencephalic crest, which can make ACh before explantation, always synthesized ACh after $7 \mathrm{~d}$ in culture and often, but not invariably, elaborated small quantities of CA as well. Association with 2-d somite and notochord, 2-d heart, or 4-d hindgut, in medium supplemented with horse serum, resulted in the synthesis of increased amounts of both transmitters. ACh-synthesizing activity was lower and the cholinergic-stimulating effects of somite and heart were abolished in the presence of fetal calf serum. Cervicothoracic (trunk) crest, taken from the level where the dorsal mesoderm is still unsegmented, always produced ACh after culture, but CA was detectable only when the cultures were obtained by initially explanting the entire neural primordium. Co-culture of trunk crest with young embryonic tissue increased ACh-synthesizing ability and initiated CA production.

Despite their capacity to elaborate neurotransmitter, cultures of either type of neural crest, alone or in association with the above-mentioned tissues, contained very few cells resembling neurons in their phase contrast appearance and none that reacted positively to any of the cytological tests applied. On the other hand, when the sclerotomic moiety of 3-d somite was cultured, trunk neural crest cells that had already migrated into the rudiment in vivo but which had not yet begun to produce detectable amounts of CA underwent rapid differentiation into neurons that synthesized and accumulated large quantities of CA. Stores of CA were detectable cytochemically as early as 24 $\mathrm{hr}$ after explantation and the presence of many small, dense core vesicles in neurons and processes was revealed by electron microscopy. ACh-synthesizing activity, demonstrable in freshly dissected sclerotomes, was also present in all of the cultures examined.

These results show that (1) during ontogeny, cholinergic traits appear earlier than adrenergic ones in the neuronal precursors contained in the neural crest; (2) some decisive step in the differentiation of the precursor cells of the sympathetic ganglia takes place in vivo within a few hours of the onset of trunk neural crest migration. This coincides with a maturation of the somitic mesenchyme. A similar developmental process does not occur in vitro when 2-d somites and neural crest are associated in histiotypic cultures.
\end{abstract}

The differentiation of cells of the autonomic nervous system has been the subject of active research in recent

\footnotetext{
' This work, carried out with the technical assistance of C. Breant and J. Millet, was supported financially by the Centre National de la Recherche Scientifique, the Délégation Générale à la Recherche Scientifique et Technique, and by Grant 1 R01 DE04257-01 CBY from the National Institutes of Health.

${ }^{2}$ To whom correspondence should be addressed at Institut d'Embryologie du Centre National de la Recherche Scientifique et du Coltège de France, 49 bis, Avenue de la Belle Gabrielle, 94130 Nogentsur-Marne, France.
}

years (for reviews, see Patterson, 1978; Bunge et al., 1978; Le Douarin, 1980). Not only is it well established that the autonomic ganglion cells arise in the neural crest, a transient embryonic structure, but the level of origin of the various cell types (parasympathetic, enteric, sympathetic, adrenomedullary) has been determined precisely in the avian embryo (Le Douarin and Teillet, 1973). By means of several different experimental approaches, we have obtained evidence that the phenotype expressed by the precursors of autonomic neurons depends on environmental cues arising from the non-neuronal embryonic 
tissues through which they migrate (Le Douarin and Teillet, 1974; Le Douarin et al., 1975; Smith et al., 1977). Furthermore, environmental factors can still intervene at a relatively advanced stage of neuronal development. Thus, a shift of chemical differentiation from adrenergic to cholinergic can be obtained experimentally in cultured sympathetic neurons (see Patterson, 1978). Conversely, in vivo transplantation experiments reveal that the fate of cholinergic ganglion cells can be changed and adrenergic differentiation can be elicited in them (Le Douarin et al., 1975).

Identification of the tissues influencing the very earliest stages of autonomic neuron differentiation has been the object of a number of studies. Concerning the initial development of sympathetic neurons, the experiments of Cohen (1972) suggested that the adrenergic phenotype appeared in crest cells issued from the trunk level in response to the tissues encountered during their migration, i.e., the neural tube and the somitic mesenchyme. Similar conclusions were reached by Norr (1973). In addition, an important role for the notochord in adrenergic development has been demonstrated (Teillet et al., 1978). In contrast, acetylcholine (ACh) can be synthesized already by mesencephalic crest cells when they leave the neural primordium (Smith et al., 1979). However, although the initiation of cholinergic differentiation may well be intrinsic in at least some neural crest cells, factors of non-neuronal cell origin can play a role in the subsequent stages of maturation. The gut wall was shown to do so in ovo (Le Douarin and Teillet, 1974; Le Douarin et al., 1975; Smith et al., 1977) and certain tissues, such as heart and skeletal muscle, are sources of factors affecting morphological and biochemical development of embryonic parasympathetic neurons in vitro (Helfand et al., 1978; Nishi and Berg, 1979; Adler and Varon, 1980; McLennan and Hendry, 1978, 1980).

Thus, it was of particular interest to study the ability of neural crest cells to differentiate into neurons in vitro, both in the absence and presence of cells of non-neural crest origin. Mesencephalic crest grown in culture for a week was shown to possess choline acetyltransferase (CAT) activity (Greenberg and Schrier, 1977) and trunk crest was shown to differentiate into catecholamine (CA)containing cells (Cohen, 1977). More recently, Kahn et al. (1980) have described the simultaneous acquisition of adrenergic and cholinergic properties in cultures of cranial and trunk neural crest. All of these studies were carried out with crest cultures obtained by explantation of total neural primordium, followed by withdrawal of the neural tube 24 to $48 \mathrm{hr}$ later, when the crest cells had migrated out on the dish. In view of the postulated effects of neural tube on sympathetic neuron differentiation already mentioned, it seemed worthwhile to perform similar experiments with cultures started from microsurgically excised crest explants. In addition, we wished to determine whether the pattern of crest cell differentiation in vitro was modified in the presence of some of the tissues that affect neuronal differentiation in other experimental systems.

In the present study, we have investigated the ability of isolated neural crest in culture to differentiate into autonomic neurons or their precursors as a function of its axial origin, the nature of the serum added to the medium, and the presence of other embryonic tissues of non-neural crest origin. Cholinesterase histochemistry, CA cytofluorescence, and electron microscopy were among the techniques used to reveal cytochemical development in the cultures, while biochemical differentiation was monitored routinely by measuring their synthesis of $\mathrm{ACh}$ and $\mathrm{CA}$ from radioactive precursors.

A preliminary account of some of this work has appeared (Ziller et al., 1979).

\section{Materials and Methods}

\section{Isolation of explants}

Japanese quail embryos, incubated at $38^{\circ} \mathrm{C}$, were used in all experiments.

Neural crest. Neural crest was excised microsurgically, using sharpened tungsten needles. In the trunk (cervicothoracic) region of embryos of 12 to 16 pairs of somites, the tips of the neural folds posterior to the last pair of somites were taken (Fig. 1). Each fragment of trunk crest so obtained contained about 600 cells. Mesencephalic

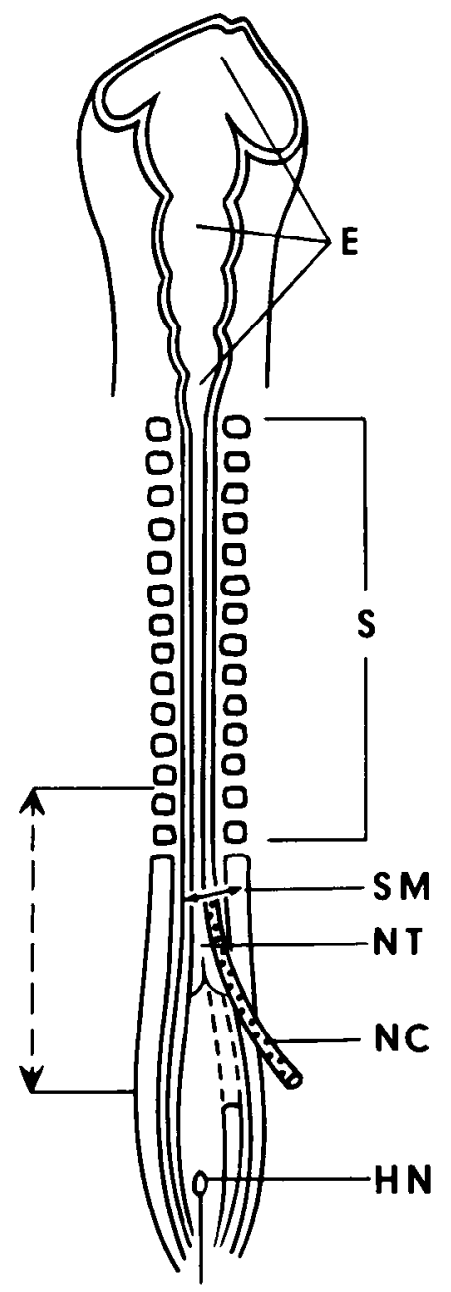

Figure 1. Diagram showing the levels from which trunk neural crest was taken. The solid arrows indicate the point of excision of the neural fold in the unsegmented region of a 14somite embryo. The dashed arrows encompass the length of total neural primordium removed when cultures were set up according to the method of Cohen and Konigsberg (1975). $E$, encephalon; $S$, somites; $S M$, unsegmented somitic mesenchyme; $N T$, neural tube; $N C$, neural crest; $H N$, Hensen's node. 


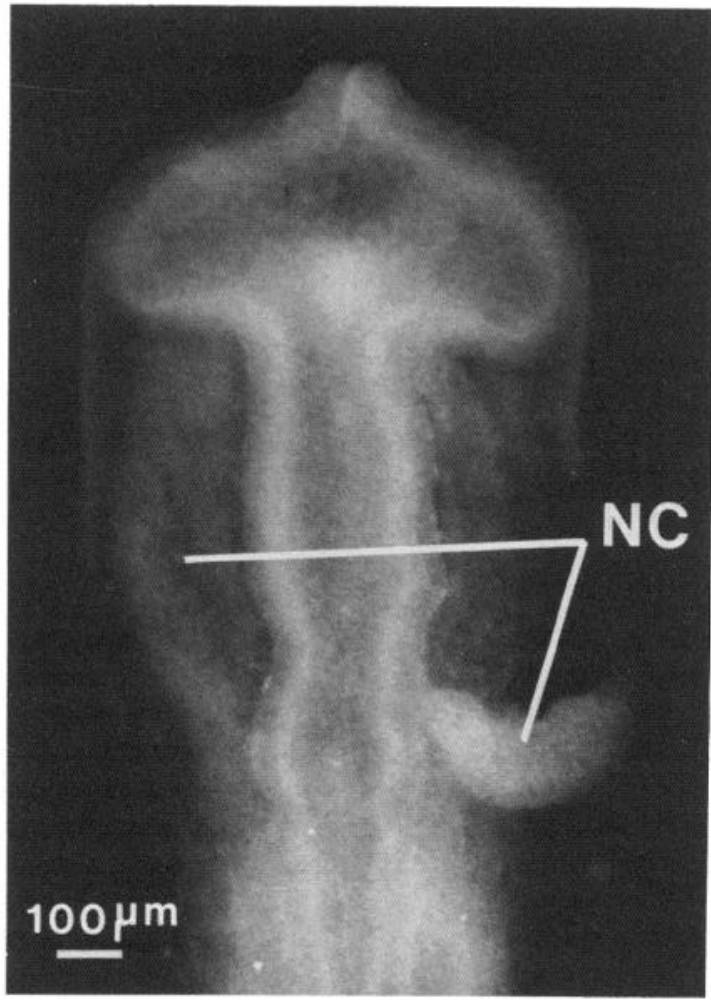

Figure 2. Dorsal view of the head of a 10-somite quail embryo. A fragment of migrating mesencephalic crest $(N C)$ has been dissected out on the right side.

neural crest was removed from embryos of 8 to 12 pairs of somites, at which stage, the cells are migrating laterally away from the mesencephalic vesicle and can be dissected out together with the overlying ectoderm (Fig. 2). Each "migrating" crest in this case contained about 1500 cells.

Histological examination (Smith et al., 1979) shows clearly that mesencephalic crest can be removed from the embryo without contamination with neural tube cells. In the case of the trunk crest, the question is more difficult to resolve since there is no clear demarcation between neural fold and neural tube. In our experiments, only the tips of the folds were taken for explantation; if part of the neural tube (i.e., the dorsal quarters of the primordium) was included purposely, neural development in vitro was extensive and numerous neurites appeared within $2 \mathrm{~d}$. This type of differentiation was never observed in our neural crest cultures.

Total neural primordium. For some experiments, the entire neural primordium (neural tube plus crest) was isolated from the trunk from the level of the penultimate somite caudad as described by Cohen and Konigsberg (1975).

Heart, hindgut, and somitic mesenchyme. The ventricular region of 2-d heart was dissected out surgically. Hindgut (the level of the intestine situated between the cecal primordia and the cloaca) was taken from 4-d embryos. The enteric wall is still aneural at this stage (Smith et al., 1977), but the developing Remak nerve has to be removed carefully from the dorsal mesentery. Un- segmented somitic mesenchyme, i.e., mesoderm posterior to the last pair of somites (Fig. 1), was obtained from 2d (14- to 18-somite stage) embryos by dissociation with $0.2 \%$ pancreatin (Gibco). Notochord, isolated at the same time, was always added to the preparation before culturing.

Sclerotomes and dermomyotomes. Sclerotomes and dermomyotomes were dissociated after proteolytic treatment of the trunk of 3-d (stage 19 of Zacchei, 1961) embryos, between the fore- and hindlimb buds, by a technique essentially the same as that described by Cheney and Lash (1981). The notochord was not included in cultures of these rudiments.

\section{Culture methods}

All tissues to be grown in culture were placed without previous dissociation in Multiwell (Falcon) tissue culture plates (well diameter, $12 \mathrm{~mm}$ ) containing a small volume (about $200 \mu \mathrm{l}$ ) of liquid culture medium. After several hours at $37^{\circ} \mathrm{C}$ in humidified $\mathrm{CO}_{2}$ :air (5:95), the explants had attached to the bottom of the wells and more medium was added to a final volume of 1 to $1.2 \mathrm{ml}$. When trunk neural crest was cultured according to the method of Cohen and Konigsberg (1975), the neural tube was removed after $48 \mathrm{hr}$ in vitro. For co-culture, non-crest tissue was grown for 4 to $7 \mathrm{~d}$ before the addition of neural crest explants.

Some cultures that were to be examined histologically were grown on glass coverslips coated with calf skin collagen.

For biochemical assays, the number of explants of crest or embryonic tissue taken to start the culture was always constant. Thus, 14 mesencephalic or trunk crest fragments ( 7 neural tubes when the total neural primordium was explanted) were initially put into culture in every case. For the different types of co-culture, the quantities of embryonic tissue used (per well) were: 4 ventricular explants, 3 hindguts (both cut into small pieces), and nonsegmented somitic mesenchyme plus notochord (total length equivalent to 3 to 4 somites) from 4 embryos, 20 sclerotomes, and 20 dermomyotomes. Routinely, the cultures were grown in $\mathrm{CO}_{2}$ :air (5:95) for $7 \mathrm{~d}$ and the medium was changed once or twice during this time.

The culture medium was Dulbecco's modified minimal essential medium (MEM) (Gibco) supplemented with $15 \%$ horse serum (HS) (Gibco) or $15 \%$ fetal calf serum (FCS) (Gibco) and 2\% 9-d chick embryo extract. In some cases, $7 \mathrm{~S}$ nerve growth factor (NGF) (a gift from Dr. Levi-Montalcini) at 5 to $10 \mu \mathrm{g} / \mathrm{ml}$ was present throughout the culture period.

\section{Histological and histochemical methods}

For the characterization of neuronal cells, Bodian's (1937) silver impregnation was used, as well as methylene blue staining (Gabe, 1968). Cholinesterase was revealed by the technique of Karnovsky and Roots (1964). CA stores in tissue sections were visualized by formaldehydeinduced fluorescence (FIF) (Falck, 1962) and in cultured cells by fluorescence induced by fixation with glyoxylic acid (GIF) (Furness and Costa, 1975). 


\section{Electron microscopy}

Whole cultures were fixed in potassium permanganate according to the technique described by Ross et al. (1977) for cultured sympathetic neurons.

\section{Biochemical techniques}

Measurement of CAT activity. Cultured cells were washed, scraped into $50 \mathrm{~mm}$ sodium phosphate, $\mathrm{pH} 7.4$, and disrupted ultrasonically. Triton X-100 then was added to a final concentration of $0.5 \%$. The conversion of $\left[1-{ }^{14} \mathrm{C}\right]$ acetylcoenzyme A (Amersham, $58 \mathrm{mCi} / \mathrm{mmol}$ ) to $\mathrm{ACh}$ by neural crest homogenates was measured by the method already described for non-cultured crest (Smith et al., 1979). Some assays were performed in the presence of $0.5 \mathrm{mM}$ 4-(1-naphthylvinyl)pyridine (NVP) (Calbiochem). Protein was determined by the Lowry method (Lowry et al., 1951). Enzyme activity was expressed as picomoles of ACh formed per min per mg of protein.

Neurotransmitter synthesis and accumulation by intact cells. Synthesis of $\mathrm{ACh}$ and $\mathrm{CA}$ was measured in cultured and non-cultured tissue by incubation with $\left[{ }^{3} \mathrm{H}\right]$ choline and $\left[{ }^{3} \mathrm{H}\right]$ tyrosine essentially as described by Mains and Patterson (1973). Each precursor, at a final concentration of $15 \mu \mathrm{M}$, was added to tissue culture medium (L-15 or Dulbecco's modified MEM) lacking choline and tyrosine. Eserine and ascorbate were added to final concentrations of $10^{-4} \mathrm{M}$ and $1.5 \times 10^{-4} \mathrm{M}$, respectively. For all cultured material, the radioactive precursors were $\left[\right.$ methyl $\left.-{ }^{3} \mathrm{H}\right]$ choline (Amersham, $6.4 \mathrm{Ci} /$ mmol) and L-[side chain-2,3- $\left.{ }^{3} \mathrm{H}\right]$ tyrosine (Amersham, 10 $\mathrm{Ci} / \mathrm{mmol}$ ). In some experiments with non-cultured crest and sclerotome, the sensitivity of the method was increased by using $\left[\right.$ methyl $\left.-{ }^{3} \mathrm{H}\right]$ choline at $36 \mathrm{Ci} / \mathrm{mmol}$ and $\mathbf{L}-\left[2,3,5,6-{ }^{3} \mathrm{H}\right]$ tyrosine at $104 \mathrm{Ci} / \mathrm{mmol}$. After incubation for $4 \mathrm{hr}$ at $37^{\circ} \mathrm{C}$ in humidified air or $\mathrm{CO}_{2}$ :air (5:95), cultured cells were scraped off the dish into formate/ acetate buffer, pH 1.9 (Hildebrand et al., 1971), containing unlabeled choline, tyrosine, noradrenaline, dopamine, and $\mathrm{ACh}$, disrupted by ultrasound, and subjected to high voltage electrophoresis for $2 \mathrm{hr}$ at $5 \mathrm{kV}$. Non-cultured material was recovered by centrifugation and treated similarly. After electrophoresis, CA spots were revealed by ninhydrin and the positions of $\mathrm{ACh}$ and choline were detected as described previously (Smith et al., 1979). Strips ( 1 or $2 \mathrm{~cm}$ wide) were cut sequentially in the appropriate regions, eluted in $1 \mathrm{ml}$ of $\mathrm{H}_{2} \mathrm{O}$, and counted after addition of $10 \mathrm{ml}$ of Readysolv $\mathrm{HP}$ scintillation fluid (Beckman) with efficiencies of approximately $50 \%$ for $\mathrm{ACh}$ and $40 \%$ for CA. Blank values were obtained from strips cut just before and after the regions of interest. The results are presented as femtomoles or picomoles of $\mathrm{ACh}$ and $\mathrm{CA}$ (noradrenaline plus dopamine, when present) synthesized and accumulated during a 4-hr incubation period per dish or per $\mathrm{mg}$ of protein. One of the major advantages of this radiochemical method is that the synthesis of both types of neurotransmitter can be evaluated in a single sample, and the results can be expressed in terms of the molar ratio of CA/ACh (Mains and Patterson, 1973). This allows convenient comparison of the relative importance of adrenergic and cholinergic properties in different types of culture.

Numerical data were analyzed using Student's $t$ test.

\section{Results}

\author{
Cultures of Neural Crest Alone
}

\section{Morphological appearance of the cultures}

During the first few hours of culture, the explants became attached to the bottom of the dish and flattened out. Cell migration from the periphery began almost immediately (Fig. $3 A$ ), but no morphological changes were apparent during the first $48 \mathrm{hr}$. The subsequent evolution of the cultures, as followed by phase contrast microscopy, was a function of the level of origin of the crest and of the type of serum present in the medium.

In FCS-supplemented medium, mesencephalic crest cells spread out widely from the explant. Generally, the cells did not aggregate and few melanocytes formed. After $7 \mathrm{~d}$, the majority of the cells were of mesenchymal or fibroblastic appearance. After extensive division, they had become arranged in multilayers at the center of the culture. Other isolated cells, at the periphery, exhibited spiky processes (Fig. $3 B$ ). A few cells with highly refringent cell bodies were sometimes visible at the edge of the dish. These neuron-like cells, which first appeared after 4 or $5 \mathrm{~d}$, possessed either many short processes or one or two long, thin ones (Fig. 3C).

In cultures of trunk neural crest, aggregates of cells often formed, and pigment cells differentiated in their vicinity 2 or $3 \mathrm{~d}$ later, increasing moderately in number up to the 7th d. Many small cells with ramifying processes were usually found at the edge of the culture. Their processes extended to other cells of the same type or made contact with flat cells.

In HS-containing medium, crest cells formed clusters which were often united after $7 \mathrm{~d}$ by fine cytoplasmic outgrowths (Fig. 3D). The detailed morphology of the different cell types developing under these conditions varied according to the axial origin of the crest explants, but the spectrum of cell types produced was similar, i.e., undifferentiated, stellate cells, fibroblast/mesenchymal cells, melanocytes, and occasional cells of neuronal appearance. After 9 to $10 \mathrm{~d}$ of culture, vacuoles or refractile inclusions appeared in the cytoplasm of many of the cells, which had, at this point, a strong tendency to detach from the substrate. 'This phenomenon, although never observed in FCS-supplemented medium, was the principal reason for the choice of $7 \mathrm{~d}$ as the maximum culture period in the biochemical studies to be described subsequently.

Thus, a few cells in the majority of cultures presented certain morphological characteristics of neurons. However, the application of specific cytochemical tests did not provide confirmation of structural neuronal differentiation: Cytoplasmic projections did not stain with silver and no Nissl granules could be seen after methylene blue treatment. Likewise, all attempts to detect intracellular CA by GIF were negative.

\section{Biochemical differentiation}

CAT activity in cell-free preparations. "Migrating" mesencephalic neural crest, freshly removed from the embryo, contains a low, but significant, basal CAT activity (Smith et al., 1979). After $7 \mathrm{~d}$ in medium supple- 

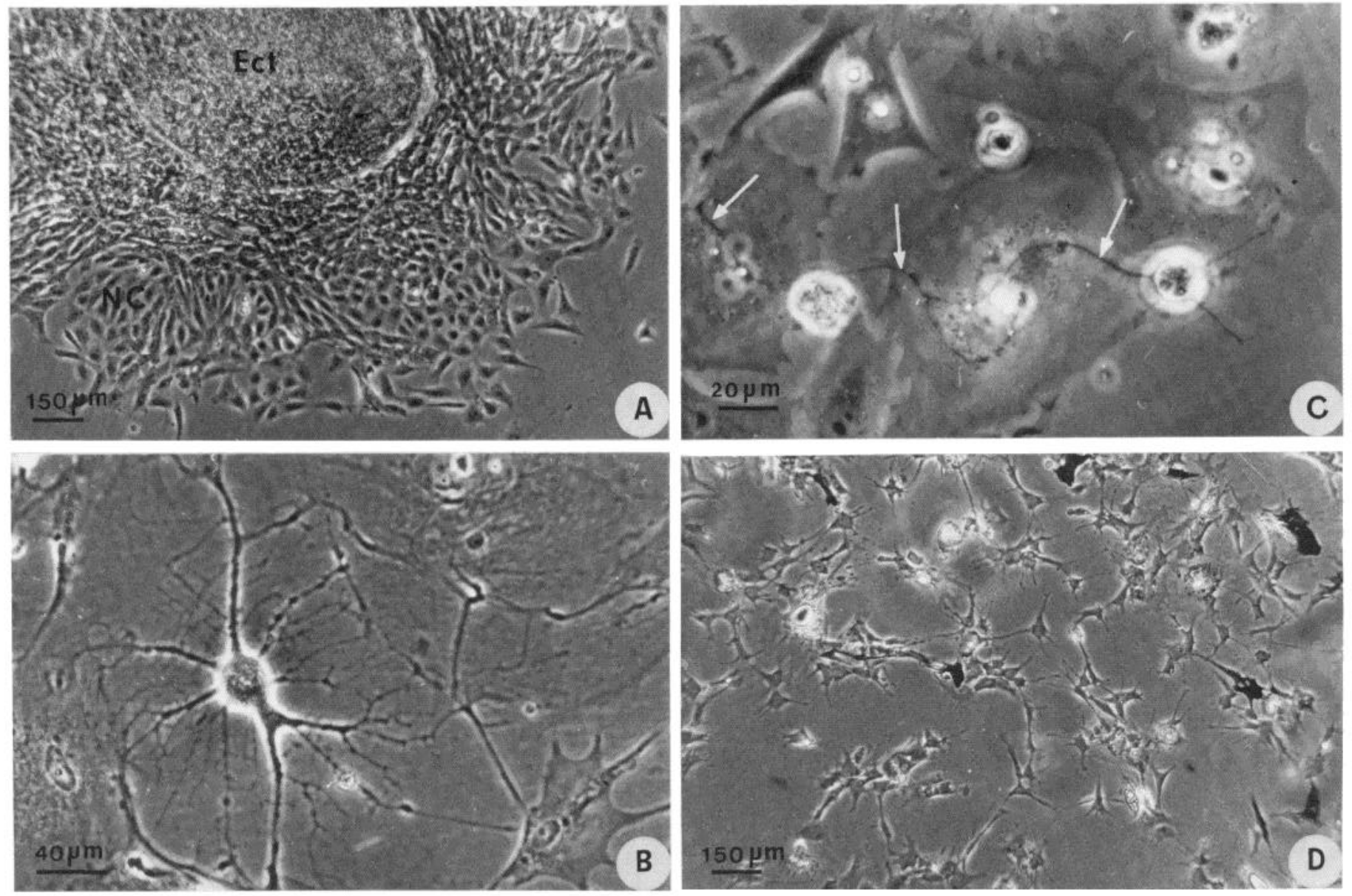

Figure 3. Phase contrast microscopy of mesencephalic neural crest cells in culture. A, After 24 hr in HS-supplemented medium. The crest cells $(N C)$, migrating away from the initial explant, whose position is marked by the sheet of ectoderm $(E c t)$, are still undifferentiated. $B$, After $7 \mathrm{~d}$ in FCS-supplemented medium. Multi-processed cell making contact with flat cells. $C$, After $7 \mathrm{~d}$ in FCS-supplemented medium. Neuron-like cell with long, sinuous process (arrows). D, After $7 \mathrm{~d}$ in HS-supplemented medium. General aspect of the culture. Several melanocytes have developed.

mented with HS, cultures of mesencephalic crest consistently contained appreciable levels of CAT. On the average, the specific activity was over 15 times higher than that found in non-cultured crest (Table I). NVP inhibited the reaction to the same extent as it did in homogenates of crest before culture. As noted previously, (Greenberg and Schrier, 1977; Ziller et al., 1979), when HS was replaced by FCS, the in vitro developmental increase of CAT was strikingly impaired, with the specific activity of the enzyme remaining at its pre-culture level.

We have been unable as yet to carry out determinations of CAT activity in uncultured cervicothoracic neural crest because of the difficulties involved in obtaining sufficient crest cells from this level of the embryo. CAT was, however, detectable in trunk crest cultures after $7 \mathrm{~d}$ in vitro in the presence of $\mathrm{HS}$, although its activity was very low (Table I).

Neurotransmitter synthesis and storage by intact cells. The ability of neural crest to synthesize neurotransmitters before and after culture is summarized in Table II. We have reported already (Smith et al., 1979) that excised mesencephalic neural crest can convert choline to ACh. This synthetic activity increased about 11-fold (with respect to the number of crest cells initially ex- planted) after $7 \mathrm{~d}$ of culture in HS-supplemented medium. A significantly lower increase (3- to 4-fold) was observed in the presence of FCS.

In contrast, no CA synthesis could be detected in any of the samples of non-cultured mesencephalic crest examined. This is not due to an inherent inability of this region of the neural crest to give rise to adrenergic cells, since a certain number of cultures grown in HS for $7 \mathrm{~d}$ produced small amounts of CA. The proportion of positive cultures was significantly greater when FCS replaced HS in the medium. As to the nature of the CA synthesized, the radioactive product co-migrated electrophoretically with noradrenaline and was also eluted with it in a high performance liquid chromatography system (M. Fauquet and J. Smith, unpublished results). No dopamine was detected.

Cultures of excised trunk neural crest in HS also produced ACh in every case, although much less than cultures started with an equivalent number of mesencephalic crest cells. No CA synthesis was detected under these conditions. Substitution of FCS for HS did not modify either ACh synthesis or the incidence of CA production; only a single culture was found to convert tyrosine to noradrenaline. Nor did the addition of NGF 
TABLE I

CAT activity in cultured and non-cultured neural crest

CAT activity was measured in homogenates of mesencephalic crest after culture in medium containing FCS or HS and of excised trunk crest after culture in HS-supplemented medium. For comparison, data for non-cultured mesencephalic crest (from Smith et al., 1979) are presented also. The values, corrected for assay blanks (routinely 45 to $65 \mathrm{cpm}$ ), are means \pm SEM. The number of determinations, each corresponding to a separate experiment, is shown in parentheses.

\begin{tabular}{|c|c|c|c|}
\hline $\begin{array}{l}\text { Origin of } \\
\text { Neural Crest }\end{array}$ & Culture Conditions & CAT Specific Activity & Inhibition by NVP \\
\hline & & pmol ACh/min $/ m g$ protein & $\%$ \\
\hline Mesencephalic & $\begin{array}{l}\text { Non-cultured } \\
\text { Cultured } 7 \mathrm{~d}+\text { FCS } \\
\text { Cultured } 7 \mathrm{~d}+\mathrm{HS}\end{array}$ & $\begin{array}{l}3.5 \pm 0.7(4) \\
3.1 \pm 0.4(7) \\
58 \pm 19(11)\end{array}$ & $\begin{array}{c}54 \pm 3(4) \\
\mathrm{ND}^{\alpha} \\
54 \pm 6(9)\end{array}$ \\
\hline Trunk & Cultured $7 \mathrm{~d}+\mathrm{HS}$ & $6.2 \pm 3.2(4)$ & $\mathrm{ND}^{a}$ \\
\hline
\end{tabular}

${ }^{a}$ ND, not determined.

TABLE II

Neurotransmitter synthesis by cultured and non-cultured neural crest

Cultures of mesencephalic and trunk crest were incubated with $\left[{ }^{3} \mathrm{H}\right]$ tyrosine and $-\left[{ }^{3} \mathrm{H}\right] \mathrm{choline}$. Transmitter synthesis is expressed as femtomoles (mean of all experiments \pm SEM) of $\mathrm{CA}$ and $\mathrm{ACh}$ formed per $4 \mathrm{hr}$ per dish, with cach culture dish initially containing 14 neural crest explants. Similar determinations were performed with 20 to 40 non-cultured mesencephalic neural crests, although the results are expressed, for conformity, as femtomoles per 14 crest fragments. Data for non-cultured crest include two experiments in which no [ $\left.{ }^{3} \mathrm{H}\right]$ tyrosine was added. The number of cases in which $\mathrm{CA}$ or $\mathrm{ACh}$ was detectable is recorded as a fraction of the total number of experiments carried out.

\begin{tabular}{|c|c|c|c|c|c|}
\hline \multirow{2}{*}{ Origin of Neural Crest } & \multirow{2}{*}{ Culture Conditions } & \multicolumn{2}{|c|}{ Number of Cases Positive for } & \multicolumn{2}{|c|}{ Quantity of Neurotransmitter Synthesized } \\
\hline & & $\mathrm{CA}$ & $\mathrm{ACh}$ & $\mathrm{CA}$ & $\mathrm{ACh}$ \\
\hline & & & & & \\
\hline \multirow[t]{3}{*}{ Mesencephalic } & Non-cultured & $0 / 6$ & $8 / 8$ & 0 & $48 \pm 14$ \\
\hline & Cultured $7 \mathrm{~d}+\mathrm{HS}$ & $4 / 11$ & $11 / 11$ & $9 \pm 5$ & $553 \pm 83$ \\
\hline & Cultured $7 \mathrm{~d}+\mathrm{FCS}$ & $9 / 10$ & $10 / 10$ & $20 \pm 4$ & $165 \pm 37$ \\
\hline \multirow[t]{2}{*}{ Trunk } & Cultured $7 \mathrm{~d}+\mathrm{HS}$ & $0 / 10$ & $10 / 10$ & 0 & $30 \pm 7$ \\
\hline & Cultured $7 \mathrm{~d}+\mathrm{FCS}$ & $1 / 9$ & $9 / 9$ & $2 \pm 2$ & $43 \pm 6$ \\
\hline $\begin{array}{l}\text { (from total neural } \\
\text { primordium) }\end{array}$ & Cultured $7 d+$ FCS & $5 / 9$ & $9 / 9$ & $12 \pm 5$ & $74 \pm 18$ \\
\hline
\end{tabular}

to the medium have any discernible effect on neurotransmitter production.

As can be seen from the last line in Table II, when crest cell cultures were obtained by initially explanting the total trunk neural primordium, catecholaminergic differentiation was enhanced: Over half of the cultures synthesized some CA under these conditions.

\section{Cultures of Neural Crest with Embryonic Tissues}

Co-cultures were examined $7 \mathrm{~d}$ after explantation of neural crest fragments either at the edge or on the surface of already established cultures of the tissues whose effects were to be studied.

\section{Morphological appearance of the cultures}

The crest cells spread out from the initial explant, showing no contact inhibition. After $48 \mathrm{hr}$, they were indistinguishable from the mesenchymal feeder layer. After $7 \mathrm{~d}$, melanocytes had differentiated in certain cultures (particularly in association with splanchnic and somitic mesenchymes and in the presence of HS). Although cells with short processes were visible occasionally (Fig. $6 A$ ), no morphological or cytochemical signs of neuronal differentiation could be observed. In particular, no fluorescent cells or processes were ever seen after glyoxylic acid treatment.

\section{Neurotransmitter synthesis in co-cultures}

In control experiments, we determined the synthesizing ability of 7- to 10-d cultures of embryonic tissue alone. There was no conversion of $\left[{ }^{3} \mathrm{H}\right]$ tyrosine to $\mathrm{CA}$ by heart or hindgut cultures and, although CA synthesis was detected in about $25 \%$ of somite cultures, the amounts measured were very low ( $6 \pm 3 \mathrm{fmol}, n=19$ ). Cultures of somitic mesenchyme also produced small quantities of ACh $(45 \pm 11 \mathrm{fmol}, n=19)$. These synthetic activities, which probably reflect the presence of a few neural crest cells in the somitic mesenchyme at the time of explantation, are insignificant compared to those measured in the majority of co-cultures with exogenous crest.

In the presence of neural crest, both the nature of the associated tissue and the source of the serum added to the culture medium were able to modulate the absolute or relative amounts of neurotransmitter synthesized, but their effects were not identical for each type of crest.

The results of the interplay of these three factors are summarized in Figure 4 and Table III.

Mesencephalic neural crest. All co-cultures with mesencephalic crest synthesized ACh and, in the presence of HS, the amounts produced, in all cases, were considerably higher (4- to 6-fold) than those produced by cultures of crest alone. In FCS-supplemented medium, however, only hindgut was stimulatory, and co-cultures with all 

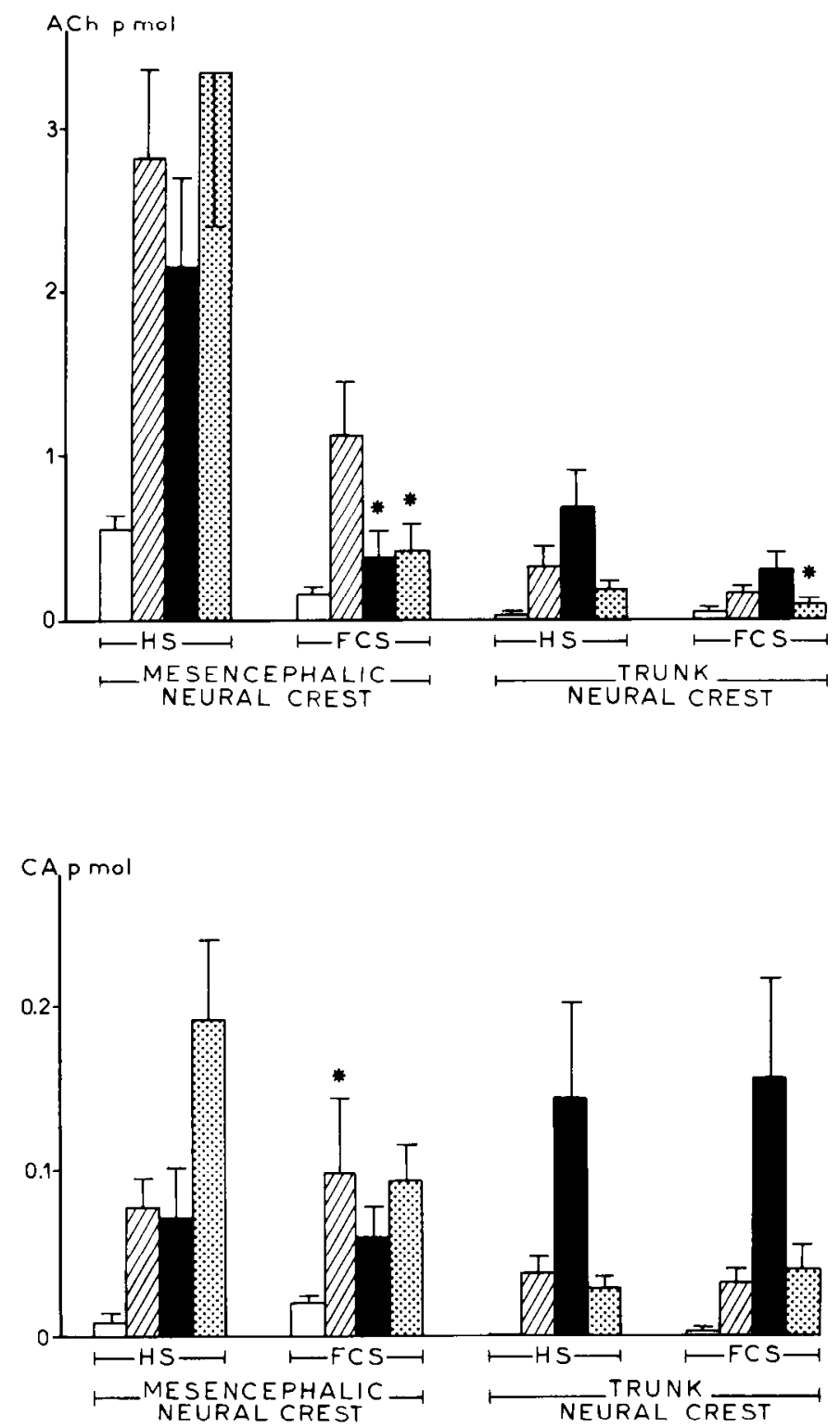

Figure 4. ACh and CA synthesis by cultures of neural crest alone or in association with embryonic tissue. $\square$, crest alone; $\mathbb{Z}$, crest plus 4 -d hindgut; $\square$, crest +2 -d somite; 同, crest +2 -d heart. Results are expressed as picomoles of transmitter synthesized (mean \pm SEM) per dish during a 4-hr incubation with $\left[{ }^{3} \mathrm{H}\right]$ choline and $\left[{ }^{3} \mathrm{H}\right]$ tyrosine (see "Materials and Methods"). For number of determinations, see Table III. *, no significant difference $(p>0.05)$ compared to cultures of neural crest alone.

three tissues produced much less ACh than they did in HS. As a consequence, the mean $\mathrm{CA} / \mathrm{ACh}$ ratio obtained was always higher in FCS-containing medium $(p<0.05)$.

Nearly every co-culture was able to convert tyrosine to $\mathrm{CA}$ and this synthetic activity was higher than in cultures of crest alone except in one case (the stimulation of CA synthesis by hindgut in FCS medium was not statistically significant).

Trunk neural crest. Association of trunk neural crest with all three tissues also resulted in a general stimulation (up to 20-fold) of ACh synthesis, which was accompanied by CA production in the great majority of the cultures. In this respect, the contrast with trunk crest alone was particularly striking. As already observed in cultures of trunk crest by itself, the nature of the serum present in the medium had no statistically significant effect on the synthesis of either neurotransmitter by mixed cultures. Interestingly, all co-cultures with trunk crest in medium containing HS had higher $\mathrm{CA} / \mathrm{ACh}$ ratios than the corresponding co-cultures with mesencephalic crest $(p<$ $0.05)$. This effect was observed also in FCS medium with hindgut $(p<0.02)$. NGF had no noticeable action on the synthesis of either CA or ACh in mixed cultures.

These results show that neural crest from the cranial and cervicothoracic levels can give rise simultaneously to cells producing $\mathrm{CA}$ and $\mathrm{ACh}$ and that the synthesis of both types of transmitter can be stimulated by the presence of other embryonic rudiments. None of the tissues examined completely suppressed the synthesis of either transmitter. However, not all of them stimulated CA and $\mathrm{ACh}$ to the same extent. This quantitative selectivity can be appreciated best by comparing $\mathrm{CA} / \mathrm{ACh}$ ratios for each type of co-culture (Table III). For all combinations of crest and serum, the order of ability to stimulate CA synthesis preferentially is heart $>$ somite + notochord $>$ hindgut. Significant differences were obtained only with mesencephalic crest, however; co-cultures with hindgut had lower $\mathrm{CA} / \mathrm{ACh}$ ratios than mixed cultures with cardiac mesenchyme ( $p<0.05$ and $p<0.01$ in HS and FCS, respectively).

In all co-cultures examined, $\mathrm{CA} / \mathrm{ACh}$ values were invariably in favor of ACh. For comparison, synthesis of the two transmitters by sympathetic chain ganglia, taken from 6-d quail embryos and cultured for $7 \mathrm{~d}$ in FCS medium, was measured under conditions identical to those used for crest cultures. A mean CA/ACh ratio of $3.053 \pm 0.976$ was obtained in six experiments. This figure is much higher than that characteristic of co-cultures of trunk crest with somitic mesenchyme, a tissue in which sympathoblasts mature in vivo but which clearly was not allowing their satisfactory development in histiotypic culture. Our subsequent experiments aimed at devising conditions that would lead to a much more complete expression of the adrenergic phenotype in vitro.

\section{Sympathoblast Differentiation in 3-Day Somites Cultured In Vitro}

In the avian embryo of $3 \mathrm{~d}$, the somitic mesoderm has differentiated into two morphologically distinct components, the dermomyotome (anlage of the dermis and striated muscle) and the sclerotome (which will give rise to the vertebrae). It is within the latter that neural crest cells migrate from the cervicothoracic neural tube and condense to form the dorsal root ganglia and primary sympathetic chains. It is reasonable to suppose that the dermomyotome plays no part in the adrenergic differentiation process; indeed, as a source of skeletal muscle, it may well have an opposite (i.e., cholinergic-stimulating) effect on neuroblast development (e.g., Giller et al., 1973). Therefore, we decided to dissociate isolated somites into their two components in order to examine neural crest cell differentiation in the sclerotomic environment in the absence of any possible influence of the muscle rudiment.

'The sclerotomic moiety of somites from 3-d embryos already contains migrating neural crest cells, but the 
TABLE III

The effect of co-culture with young embryonic tissue on neurotransmitter synthesis in neural crest cultures

Excised mesencephalic or trunk crest (14 crest fragments/well) was cultured for $7 \mathrm{~d}$ in the presence of 4-d hindgut, 2-d somites (plus notochord), or 2-d heart in HS- or FCS-supplemented medium. Synthesis of CA and ACh was determined as described under "Materials and Methods." All cultures produced $\mathrm{ACh}$, and the number synthesizing both transmitters is recorded as a fraction of the total number of dishes examined. The cultures of neural crest alone were the same as those analyzed in Table II. The total quantities of CA and ACh made per culture are shown in Figure 4. Here, the expression of neurotransmitter production as the ratios of CA to $\mathrm{ACh}$ formed (means of the ratios for each culture $\pm \mathrm{SEM}$ ) helps to reveal differential effects of co-cultured tissue on CA- or ACh-synthesizing ability.

\begin{tabular}{|c|c|c|c|c|}
\hline $\begin{array}{l}\text { Origin of Neural } \\
\text { Crest }\end{array}$ & $\begin{array}{l}\text { Associated Embryonic } \\
\text { Tissue }\end{array}$ & Serum & $\begin{array}{c}\text { Number of Cultures Syn- } \\
\text { thesizing CA and ACh }\end{array}$ & $\begin{array}{l}\text { Molar Ratio: } \\
\text { CA/ACh }\end{array}$ \\
\hline \multirow[t]{8}{*}{ Mesencephalic } & None & HS & $4 / 11$ & $0.012 \pm 0.005$ \\
\hline & Hindgut & HS & $10 / 11$ & $0.030 \pm 0.005$ \\
\hline & Somites + notochord & HS & $8 / 9$ & $0.032 \pm 0.010^{a}$ \\
\hline & Heart & HS & $14 / 14$ & $0.068 \pm 0.015$ \\
\hline & None & FCS & $9 / 10$ & $0.165 \pm 0.041$ \\
\hline & Hindgut & FCS & $10 / 10$ & $0.073 \pm 0.013$ \\
\hline & Somites + notochord & FCS & $7 / 8$ & $0.268 \pm 0.100^{a}$ \\
\hline & Heart & FCS & $14 / 15$ & $0.377 \pm 0.071$ \\
\hline \multirow[t]{8}{*}{ Trunk } & None & HS & $0 / 10$ & 0.000 \\
\hline & Hindgut & HS & $8 / 9$ & $0.164 \pm 0.041$ \\
\hline & Somites + notochord & HS & $9 / 10$ & $0.236 \pm 0.071$ \\
\hline & Heart & HS & $8 / 10$ & $0.497 \pm 0.216$ \\
\hline & None & FCS & $1 / 9$ & $0.043 \pm 0.043$ \\
\hline & Hindgut & FCS & $9 / 10$ & $0.279 \pm 0.072$ \\
\hline & Somites + notochord & FCS & $8 / 8$ & $0.438 \pm 0.088$ \\
\hline & Heart & FCS & $9 / 12$ & $0.660 \pm 0.210$ \\
\hline
\end{tabular}

"No significant difference compared to cultures of neural crest alone $(p>0.05)$.

potential sympathoblasts have not aggregated yet into the primary ganglionic chains (Fig. 5) and no FIF is detectable in any cells at this stage. It soon became apparent that it was unnecessary to add exogenous crest to isolated sclerotomes in order to obtain satisfactory neuronal differentiation in vitro, and the results presented below describe the maturation of neural crest cells already present in the somites of the 3-d embryo.

\section{Morphological appearance of the cultures}

Completely lacking discernible neuronal characteristics at the moment of explantation, neural crest-derived cells underwent very rapid differentiation in the sclerotomic environment in vitro. As early as the 2nd day, in both HS and FCS, cells appeared with highly refractile, spherical cell bodies and long processes. In certain cultures, 10 to 30 of these cells grouped to form "ganglia." In others, smaller groups formed an intricate network (Fig. 6B). In both cases, the neuron-like cells overlay a sheet of fibroblastic cells and, after $7 \mathrm{~d}$, were often distinguishable from the other cellular elements of the culture (roughly polygonal, fibroblastic cells and occasional melanocytes). Where "ganglia" persisted, a halo of fibers radiated from their periphery. In most cultures, nodules of cartilage were present also. In the 7-d cultures, treatment with silver revealed an intense staining of the processes of morphologically neuron-like cells. Nissl granules were visible also in certain spherical cells after methylene blue treatment (Fig. 7A). Similarly, cholinesterase-positive cell bodies and fibers could be demonstrated (Fig. $7 B$ ). CA could be detected by GIF in neuronlike cells in all cultures tested, from $24 \mathrm{hr}$ onward. After
$7 \mathrm{~d}$, the intensity of the fluorescence in the cell bodies was variable: Very strong in some, it consisted of a barely distinguishable perinuclear halo in others. Fluorescent cells were grouped mainly in aggregates. Fibers and varicosities were very strongly positive (Fig. $7 \mathrm{C}$ ).

Study of sclerotome cultures at the electron microscope level after permanganate fixation revealed typical features of young, developing sympathetic neurons. In particular, numerous small, dense core vesicles, with a mean diameter of $62 \pm 9 \mathrm{~nm}(n=250)$, were disseminated in the cell bodies (Fig. $8 A$ ) and in processes (Fig. $8 B$ ). Other cells containing larger dense core vesicles, with diameters of up to $170 \mathrm{~nm}$, were abundant (Fig. $8 C$ ).

In dermomyotome cultures, myoblasts and myotubes were seen regularly, but, in marked contrast to the results obtained with sclerotome, few neuronal cells differentialed and none was GIF-positive.

\section{Biochemical differentiation: Neurotransmitter} synthesis in cultures of sclerotome and dermomyotome

Freshly removed sclerotomes did not synthesize detectable CA in vitro but did produce small amounts of ACh. This cholinergic activity was confirmed by the demonstration of CAT in cell-free extracts of non-cultured rudiments (results not shown). In cultured sclerotomes, CA-synthesizing activity appeared almost immediately: As early as $20 \mathrm{hr}$ after explantation, appreciable conversion of $\left[{ }^{3} \mathrm{H}\right]$ tyrosine to $\mathrm{CA}$ was demonstrable. CA was produced in every culture examined after 1 to $9 \mathrm{~d}$ in vitro. At $7 \mathrm{~d}$, the synthetic activity was more than 10 times higher than that observed at $24 \mathrm{hr}$. ACh synthesis also was demonstrated in every culture; an increase sim- 


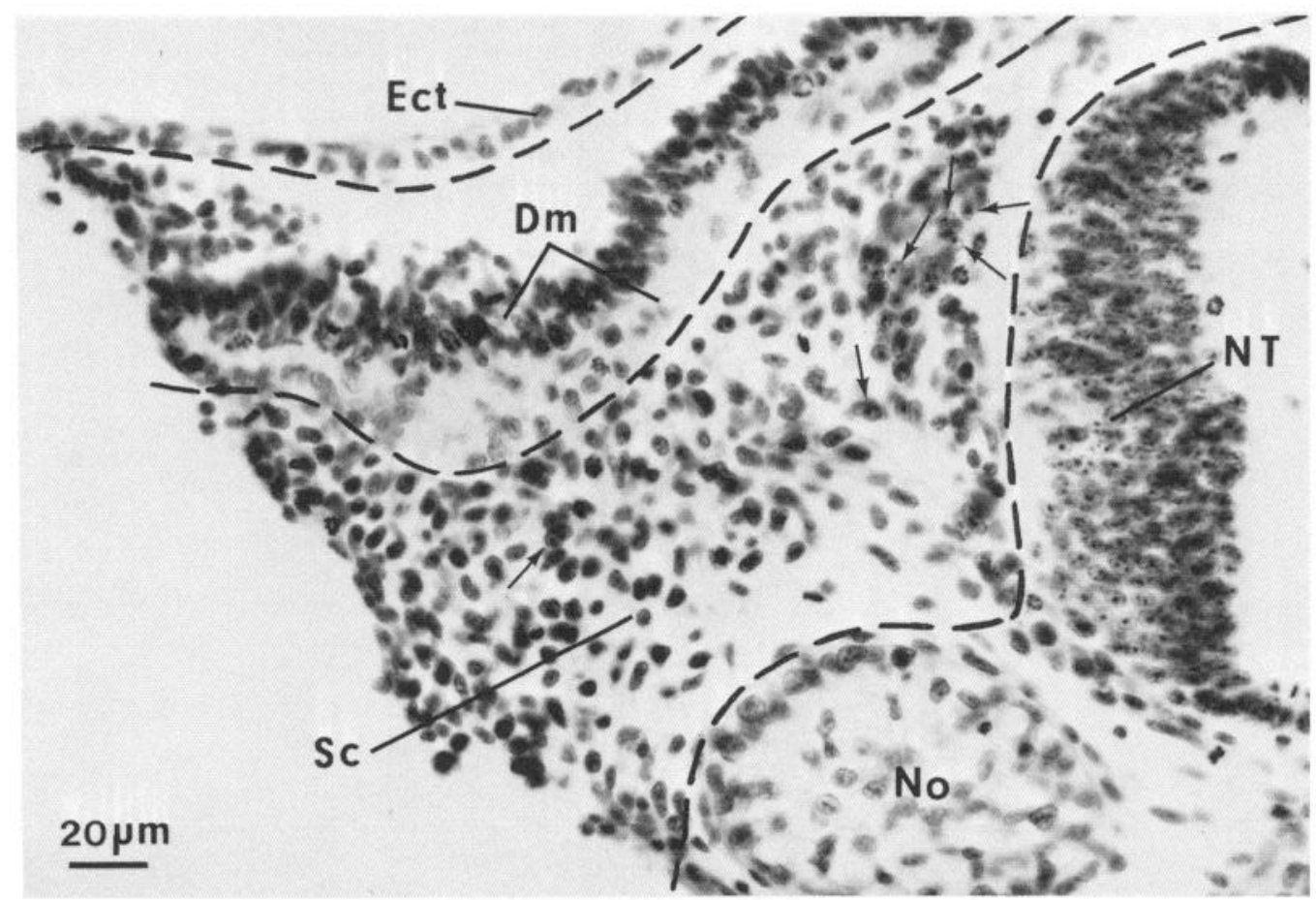

Figure 5. Transverse section of the trunk of a 3-d chimeric chick-quail embryo. At 2 d, the cervicothoracic neural primordium of a chick host was replaced by that of a quail embryo. Quail cells can be identified in the preparation as a result of their distinctive nucleolar marker (Le Douarin, 1969). Arrows point to migrating, crest-derived quail cells. The dashed lines demarcate the dermomyotomal $(\mathrm{Dm})$ and sclerotomic $(\mathrm{Sc})$ rudiments of the somite. Ect, ectoderm; No, notochord; NT, neural tube. Feulgen-Rossenbeck staining was used.

ilar to that observed for CA production occurred between 1 and $7 \mathrm{~d}$. However, the mean CA/ACh ratio for $7-\mathrm{d}$ cultures in FCS was well in favor of CA, reflecting a much more adrenergic situation than that obtained in cultures of trunk crest with 2-d somitic mesenchyme and very similar to that found in cultures of young sympathetic ganglia (see above). Furthermore, the absolute quantity of CA accumulated in sclerotome cultures during the 4-hr incubation was proportionately much greater than that found in crest/somite co-cultures. After $7 \mathrm{~d}$ in culture, 20 sclerotomes made approximately 50 times more CA than excised trunk crest of a total length equivalent to 20 somites and cultured under the same conditions with 2-d somitic mesenchyme.

The principal results are summarized in Table IV, in which, for comparison, neurotransmitter synthesis by dermomyotomes after $7 \mathrm{~d}$ in vitro is also presented. Although some cultures of the latter synthesized both $\mathrm{CA}$ and $\mathrm{ACh}$ (reflecting the presence of a few neural crest cells in isolated dermomyotomal rudiments), the quantities produced were very much smaller and the mean $\mathrm{CA} / \mathrm{ACh}$ ratio was markedly lower than in cultures of sclerotome.

\section{Discussion}

The studies described here show that a certain degree of morphological and biochemical differentiation can be expressed by neural crest cells explanted in vitro in the total or virtual absence of tissues of non-crest origin. As far as transmitter-related properties are concerned, cultures of cells from both mesencephalic and cervicothoracic levels of the crest were always able to synthesize $\mathrm{ACh}$ and could also, but only under certain conditions, produce CA. These observations provide a biochemical confirmation of the dual potentialities of neural crest revealed by transplantation experiments and extend the previous reports of Greenberg and Schrier (1977) and Cohen (1977), who showed, respectively, that, in culture, chick mesencephalic crest manifests CAT activity and quail trunk crest differentiates into cells that display CA fluorescence. While our paper was in preparation, Kahn et al. (1980) described the development both of ACh- and CA-synthesizing enzymes in cultures of quail cranial and trunk neural crest.

With regard to cholinergic differentiation, the specific activities of CAT in cultured crest that we present here (Table I) are within the range of those published by the other groups. In addition, we have shown the existence of CAT in mesencephalic crest before culture (Smith et al., 1979). Greenberg and Schrier (1977) found low CAT activity in freshly dissected neural tubes (including neural crest), but Kahn et al. (1980) could not detect the enzyme in any crest cultures before $5 \mathrm{~d}$ in vitro. However, the technique that they used would not enable very low levels of CAT to be measured with precision. As for cholinergic differentiation in trunk crest, Kahn et al. (1980) showed that the CAT detectable after several days in vitro was inhibited by NVP. ACh synthesis in our trunk crest cultures, therefore, was most probably due to 

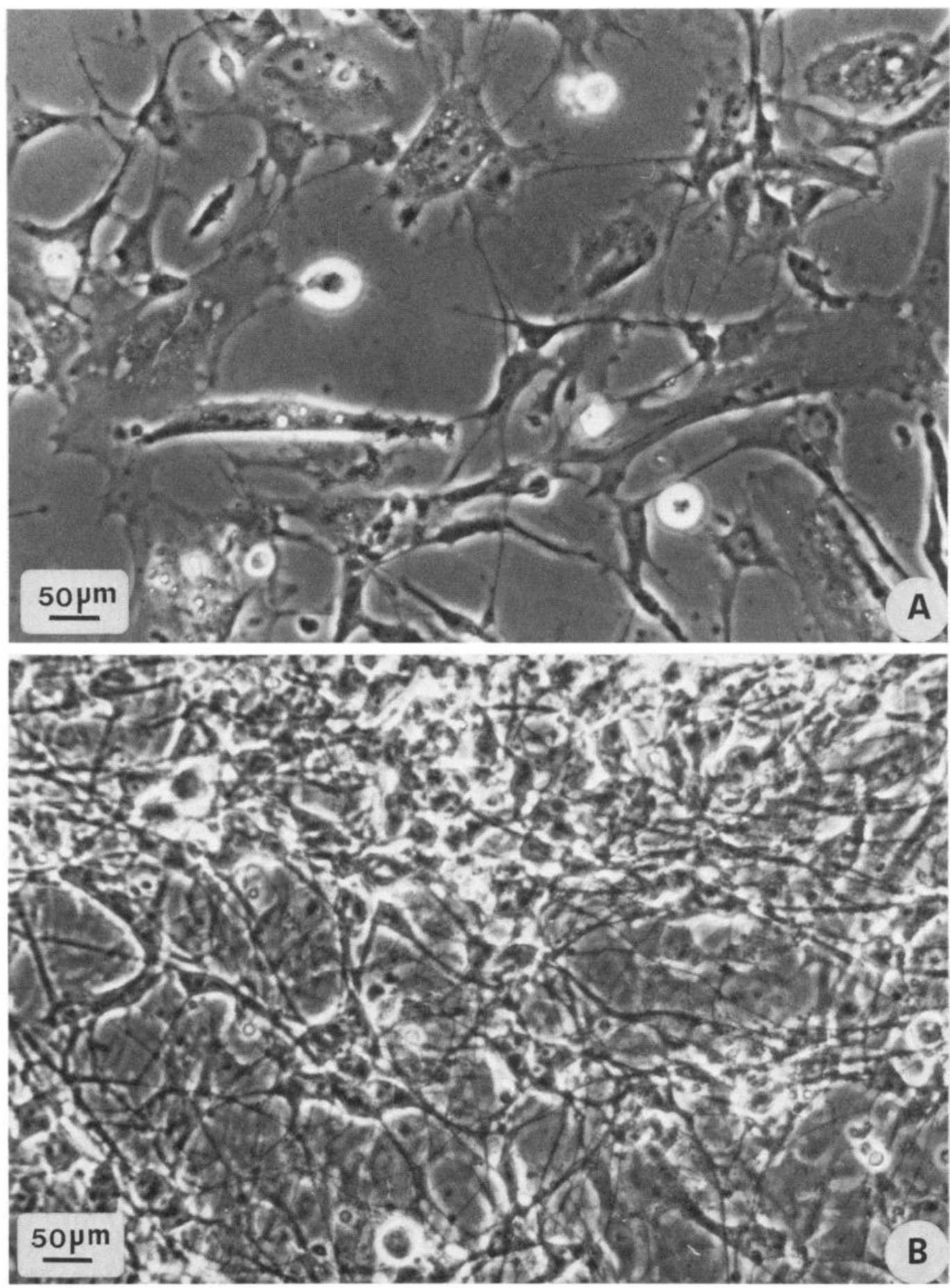

Figure 6. Development of neural crest in association with somitic mesoderm in vitro. A, Coculture of trunk neural crest with 2-d somite after $7 \mathrm{~d}$ in FCS-supplemented medium. $B$, Neural crest-derived neurons and dense network of processes in 7-d culture of 3 -d sclerotomic rudiments in FCS-supplemented medium. Phase contrast microscopy was used.

this enzyme (Table I). On the other hand, it is difficult to exclude the possibility that derivatives of a few neural tube cells, carried over in some cases when the crest was excised (see "Materials and Methods: Isolation of explants; Neural crest"), contributed to the enzymic activity. However, ACh production by cultured sclerotomes (Table IV), in which contamination by the neural tube can be ruled out, indicates that trunk crest can indeed develop cholinergic properties. Furthermore, the consistent presence of ACh-synthesizing activity in sclerotomic rudiments prior to culture provides indirect evidence that such properties exist in trunk crest cells at a very early stage in vivo.

Although certain cholinergic properties are demonstra- 

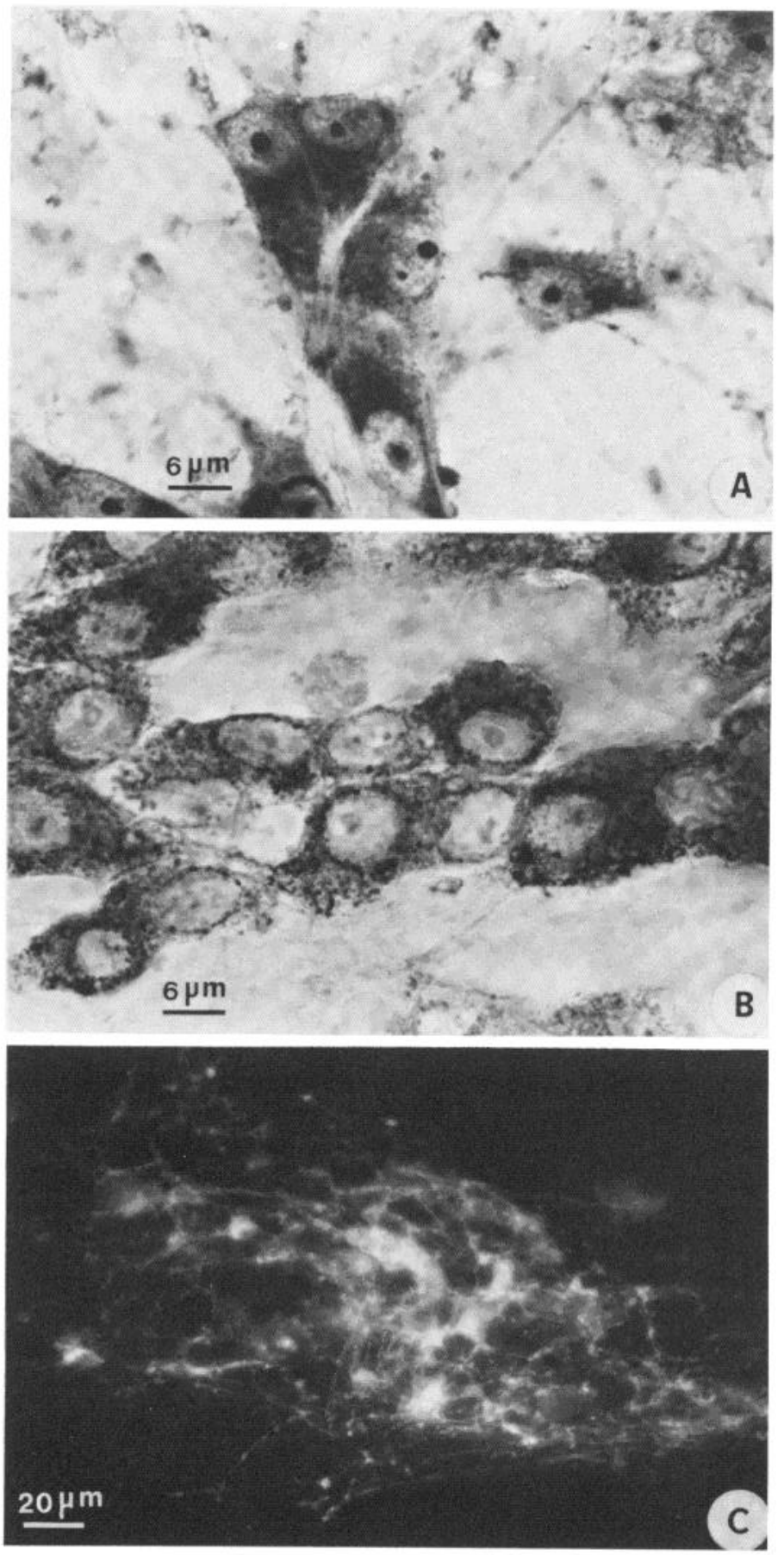

Figure 7. Neuronal differentiation in 7-d sclerotome cultures grown in FCS-supplemented medium. $A$, Methylene blue staining of Nissl granules. $B$, Histochemical revelation of cholinesterase according to the method of Karnovsky and Roots (1964). $C$, Fluorescent cells, fibers, and varicosities after glyoxylic acid fixation.

ble from the onset in neural crest, adrenergic characteristics seem to be acquired secondarily. We were unable to detect CA synthesis before culture, either in migrating mesencephalic crest or in sclerotomes already seeded with trunk crest, nor could dopamine $\beta$-hydroxylase be detected in freshly dissected neural primordium by Kahn et al. (1980). After several days in vitro, however, mes- encephalic crest synthesized low levels of CA (Table II). In contrast, biochemically detectable CA synthesis was absent in virtually all of our cultures of trunk crest alone. This result is surprising in view of the origin of peripheral sympathoblasts from this level of the axis. Furthermore, Cohen (1977) and Kahn et al. (1980) described extensive adrenergic differentiation in cultures of trunk crest: After $1 \mathrm{~d}$, dopamine $\beta$-hydroxylase was measurable, weak FIF appeared after $4 \mathrm{~d}$, and $2 \mathrm{~d}$ later, the fluorescence had become intense. This contradiction with our present results may be partly due to the fact that, for our cultures, trunk crest was excised in the posterior, nonsegmented region of the embryo (see Fig. 1) and thus was at an earlier developmental stage than that taken by Cohen and his colleagues. In addition, the presence of the neural tube during the first few hours of culture appears to favor subsequent adrenergic differentiation (Table II). However, in our hands, the amounts of CA produced in these experiments were small. Note that Cohen and Konigsberg (1975) and Kahn et al. (1980) underline the variability of neuronal differentiation in crest cultures. Perhaps differences in embryo extract or serum batches contribute to the divergences between the results of these authors and our own.

That serum contains factors that can play an important role in crest cell development is clear from a comparison of the effects of HS and FCS on cholinergic differentiation: Not only was ACh synthesis in all mesencephalic crest cultures and co-cultures markedly lower in FCS but the stimulatory effect of heart and somites was abolished (Fig. 4). The fact that CAT activity in mesencephalic crest cell cultures is much higher in the presence of HS has been stressed already by Greenberg and Schrier (1977). On the other hand, the level of CA synthesis in our crest cell cultures was not generally affected by the presence of FCS in the medium.

One of the principal aims of this study was to examine the possible role of non-neuronal embryonic tissues in peripheral nerve cell development. It is assumed that, in such mixed cultures, neurotransmitter was produced only by neural crest derivatives; there is no reason to suppose that an induction of this synthetic activity in mesenchymal and heart cells can occur under the influence of neural crest. All three types of tissue were able to stimulate ACh synthesis significantly when cultured with neural crest in the presence of HS, although they could not always do so in FCS-supplemented medium (Fig. 4). At the same time, adrenergic differentiation appeared in virtually every culture, both with mesencephalic and trunk crest, regardless of the type of serum present (Table III).

As far as the stimulatory effect on ACh synthesis is concerned, our results are consistent with those obtained by other workers using different systems. A variety of mammalian tissues, including skeletal muscle and heart, has been shown to contain factors that can stimulate CAT in central and peripheral neurons (Giller et al., 1973; Patterson and Chun, 1977; McLennan and Hendry, 1980; Godfrey et al., 1980). Since both intestinal and somitic mesenchyme give rise to muscular components, increased ACh synthesis in their presence is not surprising. However, the gut wall mesenchyme (normal sub- 
strate for the differentiation of cholinergic enteric ganglia) appears to be the most effective in this respect, since it was the only tissue capable of stimulating ACh synthesis by mesencephalic crest in FCS medium.

The appearance of CA in all types of culture is, at first sight, rather more perplexing. In particular, the ability of hindgut mesenchyme to stimulate $C A$ synthesis in vitro is in marked contrast to its behavior in grafts on the chorioallantoic membrane (Le Douarin and Teillet, 1974; Teillet et al., 1978). Differences in the techniques employed to reveal CA production in the two types of experiment are perhaps responsible; adrenergic cells were identified in in ovo experiments by the FIF technique, less sensitive than the method of detection used here. (No FIF-positive cells were found in any of our mixed crest/mesenchyme cultures.) It should be noted that CAcontaining cells do occur transiently in normal mammalian gut (Cochard et al., 1978; Teitelman et al., 1979), although their existence in birds has not been described. As for the role of cardiac cells in neuronal differentiation, Patterson and Chun (1977) have shown that rat heart contains a factor that can act on neonatal rat sympathetic neurons in vitro by strongly enhancing CAT activity while depressing CA-synthesizing ability; in our experiments, when crest cells were cultured with quail heart, although ACh synthesis was indeed increased (in HScontaining medium), CA production was stimulated even more (Fig. 4). This discrepancy is perhaps partly explicable by the differences in age of the neural cells under study, i.e., the factors involved are not acting on cells at the same stage of maturation. Furthermore, the effect of the "cholinergic factor" was species specific: Medium conditioned by chick embryo heart did not modify the synthesis of either transmitter in rat sympathetic neurons (Patterson and Chun, 1977).

In the chick, using in vivo or organ culture techniques, Cohen (1972) and Norr (1973) concluded that the appearance of FIF-positive cells was highly dependent on somitic mesenchyme (the normal substrate for sympathoblast development). Under our histiotypic culture conditions, however, only a primitive degree of neuronal maturation was attained and thus, our data concern the earliest stages of differentiation of neural crest cells into immature neuronal precursors in which adrenergic development is revealed by a sensitive radiochemical technique. Although, in association with trunk crest, somitic mesenchyme was indeed the most effective in stimulating CA synthesis (Fig. 4), our data show that triggering of CA production can be brought about by a variety of nonneuronal tissues. This suggests a possible explanation for the occurrence of "spontaneous" adrenergic differentiation in cultures of mesencephalic crest, which is, in contrast to cervicothoracic crest, an important source of mesenchymal ("mesectodermal") cells (see references in Le Douarin, 1980).

Little can be said at present concerning the nature of the stimulatory effects of the embryonic tissues on ACh and CA synthesis. They could be mediated by soluble factors, a number of which have been shown to affect the choice or intensity of neurotransmitter metabolism in developing neurons (Patterson and Chun, 1977; McLennan et al., 1980; Nishi and Berg, 1979; Godfrey et al., 1980; Brookes et al., 1980). Alternatively, conditions leading to high density and close packing of neural crestderived cells may result in contact-mediated modification of neurotransmitter-synthesizing activity such as that described in pheochromocytoma cells (Lucas et al., 1979). However, the possibility that our results reflect a general enhancement of survival or growth of neuronal precursors rather than specific effects on biochemical maturation cannot be excluded yet.

In contrast to the relatively modest degree of neuronal differentiation occurring in neural crest cultures and cocultures, large numbers of morphologically and biochemically identifiable nerve cells developed in cultures of isolated sclerotome. For the purposes of the present study, the sclerotome can be considered as a preparation of trunk neural crest cells plus the tissue into which they normally migrate. At the moment of explantation, i.e., while the crest cells are still migrating, no visible signs of neuronal differentiation are apparent and no CA stores can be detected histochemically nor can synthesis of CA be demonstrated biochemically. However, once in culture, differentiation is extremely rapid; the CA-elaborating enzyme system is functional within $24 \mathrm{hr}$. Neurons develop abundantly, as witnessed by the positive results

TABLE IV

Neurotransmitter synthesis by sclerotomes and dermomyotomes

Synthesis of $\mathrm{CA}$ and ACh was determined in sclerotomes before culture and after $1 \mathrm{~d}$ or $7 \mathrm{~d}$ in vitro in FCS-containing medium. Similar experiments were performed on 7- $\mathrm{d}$ cultures of dermomyotome. Neurotransmitter production is expressed both as specific and total (femtomoles per $4 \mathrm{hr}$ per 20 sclerotomes or dermomyotomes) activity. Up to 80 sclerotomes were grouped in attempts to detect CA synthesis before culture. The values are means \pm SEM (number of determinations is in parentheses).

\begin{tabular}{|c|c|c|c|c|c|}
\hline & \multicolumn{4}{|c|}{ Quantity of Neurotransmitter Synthesized } & \multirow{3}{*}{$\begin{array}{l}\text { Molar Ratio; } \\
\text { CA/ACh }\end{array}$} \\
\hline & \multicolumn{2}{|c|}{ Catecholamines } & \multicolumn{2}{|c|}{ Acetylcholine } & \\
\hline & total fmol & pmol/mg protein & total fmol & pmol/mg protein & \\
\hline \multicolumn{6}{|l|}{ Sclerotome } \\
\hline Non-cultured & $0(6)$ & $0(6)$ & $103 \pm 35$ & $10(2)$ & $0.000(5)$ \\
\hline Cultured $24 \mathrm{hr}$ & $82 \pm 25(8)$ & $\mathrm{ND}^{a}$ & $47 \pm 9(8)$ & $\mathrm{ND}^{a}$ & $2.142 \pm 0.757(8)$ \\
\hline Cultured $7 \mathrm{~d}$ & $949 \pm 113(16)$ & $45 \pm 14(11)$ & $604 \pm 130(16)$ & $32 \pm 11(11)$ & $2.473 \pm 0.372(16)$ \\
\hline \multicolumn{6}{|l|}{ Dermomyotome } \\
\hline Cultured $7 \mathrm{~d}$ & $34 \pm 11(13)$ & $0.3 \pm 0.1(8)$ & $79 \pm 15(13)$ & $0.8 \pm 0.1(8)$ & $0.349 \pm 0.098(13)$ \\
\hline
\end{tabular}

\footnotetext{
${ }^{n} \mathrm{ND}$, not determined.
} 

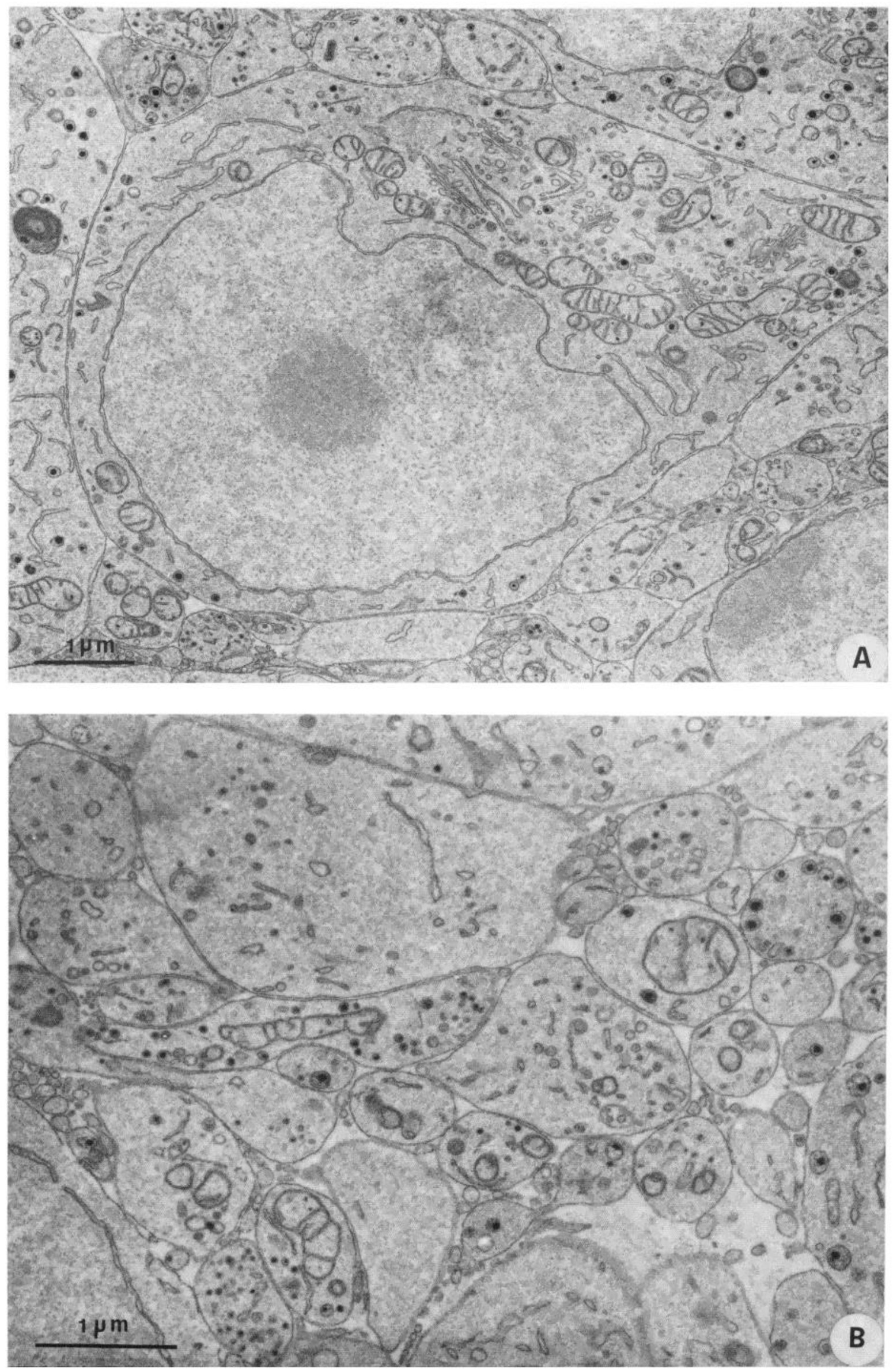

Figure 8. Electron micrographs showing dense core vesicles in cells $(A)$ and processes $(B)$ after permanganate fixation of 7-d cultures of sclerotomes grown in FCS-supplemented medium. 


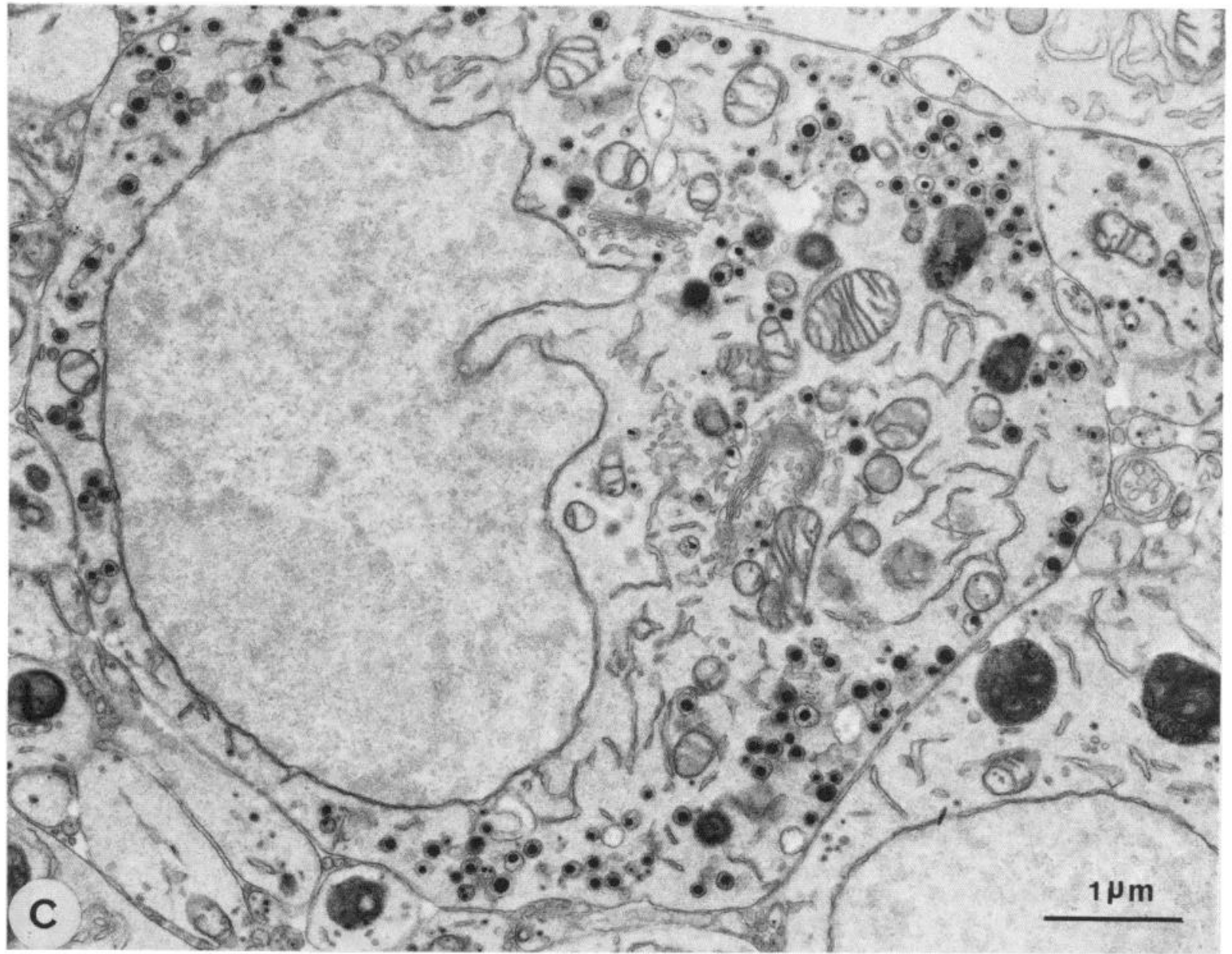

Figure 8. Continued. $C$, Other cells containing larger dense core vesicles.

of all of the specific cytochemical tests applied. It remains to be explained why younger somitic mesenchyme, even in the presence of notochord, is unable to promote the development of sympathoblasts to a similar extent. Previous experiments by our group (Teillet et al., 1978) revealed a critical role for the notochord in adrenergic differentiation. No CA-containing cells ever appeared in gut mesenchyme associated in ovo with neural primordium. However, if notochord was added, fluorescent ganglia were observed in a certain number of explants. Our present results show that the interactions between notochord and mesenchyme that create appropriate conditions for eliciting CA production do not occur in histiotypic cultures. The 3-d sclerotome presumably has already been subjected in ovo to any such developmental influences and substantial adrenergic differentiation can thus occur in vitro in the absence of notochord and neural tube. However, it does not follow necessarily that improved neurogenesis in sclerotome cultures is due entirely to the greater maturity of the somite: The neural crest cells themselves, significantly older than those cultured after excision from the neural fold, also may have undergone crucial developmental changes before their explantation.

\section{References}

Adler, R., and S. Varon (1980) Cholinergic neuronotrophic factors. V. Segregation of survival- and neurite-promoting activities in heart-conditioned medium. Brain Res. 188: 437448 .

Bodian, D. (1937) The staining of paraffin sections of nervous tissues with activated Protargol. The role of fixatives. Anat. Rec. 69: 153-162.

Brookes, N., D. R. Burt, A. M. Goldberg, and G. G. Bierkamper (1980) The influence of muscle-conditioned medium on cholinergic maturation in spinal cord cell cultures. Brain Res. 186: 474-479.

Bunge, R., M. Johnson, and C. D. Ross (1978) Nature and nurture in the development of the autonomic neuron. Science 199: 1409-1415.

Cheney, C. M., and J. W. Lash (1981) Diversification within embryonic chick somites: Differential response to notochord. Dev. Biol. 81: 288-298.

Cochard, P., M. Goldstein, and I. B. Black (1978) Ontogenetic appearance and disappearance of tyrosine hydroxylase and catecholamines in the rat embryo. Proc. Natl. Acad. Sci. U. S. A. 75: 2986-2990.

Cohen, A. M. (1972) Factors directing the expression of sympathetic nerve traits in cells of neural crest origin. J. Exp. Zool. 179: 167-182.

Cohen, A. M. (1977) Independent expression of the adrenergic phenotype by neural crest cells in vitro. Proc. Natl. Acad. Sci. U. S. A. 74: 2899-2903.

Cohen, A. M., and I. R. Konigsberg (1975) A clonal approach to the problem of neural crest determination. Dev. Biol. 46: 262-280.

Falck, B. (1962) Observations on the possibility of the cellular localization of monoamines by a fluorescence method. Acta 
Physiol. Scand. Suppl. 197, 56: 1-25.

Furness, I. B., and M. Costa (1975) The use of glyoxylic acid for the fluorescence histochemical demonstration of peripheral stores of noradrenaline and 5-hydroxytryptamine in whole mounts. Histochemistry 41: 335-352.

Gabe, M. (1968) Techniques Histologiques, Masson et Cie, Paris.

Giller, E. L., B. K. Schrier, A. Shainberg, H. R. Fisk, and P. G. Nelson (1973) Choline acetyltransferase activity is increased in combined cultures of spinal cord and muscle cells from mice. Science 182: 588-589.

Godfrey, E. W., B. K. Schrier, and P. G. Nelson (1980) Source and target cell specificities of a conditioned medium factor that increases choline acetyltransferase activity in cultured spinal cord cells. Dev. Biol. 77: 403-418.

Greenberg, J. II., and B. K. Schrier (1977) Development of choline acetyltransferase activity in chick cranial neural crest cells in culture. Dev. Biol. 61: 86-93.

Helfand, S. L., R. J. Riopelle, and N. K. Wessells (1978) Nonequivalence of conditioned medium and NGF for sympathetic parasympathetic and sensory neurons. Exp. Cell Res. 113: 39-45.

Hildebrand, J. G., D. L. Barker, E. Herbert, and E. A. Kravitz (1971) Screening for neurotransmitters: A rapid radiochemical procedure. J. Neurobiol. 2: 231-246.

Kahn, C. R., J. T. Coyle, and A. M. Cohen (1980) Head and trunk neural crest in vitro: Autonomic neuron differentiation. Dev. Biol. 77: 340-348.

Karnovsky, M. J., and L. Koots (1964) A "direct-colouring" thiocholine method for cholinesterases. J. Histochem. Cytochem. 12: 219-221.

Le Douarin, N. (1969) Particularités du noyau interphasique chez la caille japonaise (Coturnix coturnix japonica). Utilisation de ces particularités comme "marquage biologique" dans les recherches sur les interactions tissulaires et les migrations cellulaires au cours de l'ontogenèse. Bull. Biol. Fr. Belg. 103: 435-452.

Le Douarin, N. M. (1980) The ontogeny of the neural crest in avian embryo chimaeras. Nature 286: 663-669.

Le Douarin, N., and M. A. Teillet (1973) The migration of neural crest cells to the wall of the digestive tract in avian embryo. J. Embryol. Exp. Morphol. 30: 31-48.

Le Douarin, N. M., and M. A. Teillet (1974) Experimental analysis of the migration and differentiation of neuroblasts of the autonomic nervous system and of neurectodermal mesenchymal derivatives, using a biological cell marking technique. Dev. Biol. 41: 162-184.

Le Douarin, N. M., D. Renaud, M. A. Teillet, and G. H. Le Douarin (1975) Cholinergic differentiation of presumptive adrenergic neuroblasts in interspecific chimaeras after heterotopic transplantations. Proc. Natl. Acad. Sci. U. S. A. 72: 728-732.

Lowry, O. H., N. J. Rosebrough, A. L. Farr, and R. J. Randall (1951) Protein measurement with the Folin phenol reagent. J. Biol. Chem. 193: 265-275.
Lucas, C. A., D. Edgar, and H. Thoenen (1979) Regulation of tyrosine hydroxylase and choline acetyltransferase activities by cell density in the $\mathrm{PC} 12$ rat pheochromocytoma clonal cell line. Exp. Cell Res. 121: 79-86.

Mains, R. E., and P. H. Patterson (1973) Primary cultures of dissociated sympathetic neurons. I. Establishment of longterm growth in culture and studies of differentiated properties. J. Cell Biol. 59: 329-345.

McLennan, I. S., and I. A. Hendry (1978) Parasympathetic neuronal survival induced by factors from muscle. Neurosci. Lett. 10: 269-274.

McLennan, I. S., and I. A. Hendry (1980) Influence of cardiac extracts on cultured ciliary ganglia. Dev. Neurosci. 3: 1-10.

McLennan, I. S., C. E. Hill, and I. A. Hendry (1980) Glucocorticosteroids modulate transmitter choice in developing superior cervical ganglion. Nature 283: 206-207.

Nishi, R., and D. K. Berg (1979) Survival and development of ciliary ganglion neurones grown alone in cell culture. Nature 277: 232-234.

Norr, S. C. (1973) In vitro analysis of sympathetic neuron differentiation from chick neural crest cells. Dev. Biol. 34: 16-38.

Patterson, P. H. (1978) Environmental determination of autonomic neurotransmitter functions. Annu. Rev. Neurosci. 1: 1-17.

Patterson, P. H., and L. L. Y. Chun (1977) The induction of acetylcholine synthesis in primary cultures of dissociated rat sympathetic neurons. I. Effects of conditioned medium. Dev. Biol. 56: 263-280.

Ross, D., M. Johnson, and R. Bunge (1977) Development of cholinergic characteristics in adrenergic neurons is age-dependent. Nature 267: 536-539.

Smith, J., P. Cochard, and N. M. Le Douarin (1977) Development of choline acetyltransferase and cholinesterase activities in enteric ganglia derived from presumptive adrenergic and cholinergic levels of the neural crest. Cell Differ. 6: 199216.

Smith, J., M. Fauquet, C. Ziller, and N. Le Douarin (1979) Acetylcholine synthesis by mesencephalic neural crest cells in the process of migration in vivo. Nature 282: 853-855.

Teillet, M. A., P. Cochard, and N. M. Le Douarin (1978) Relative roles of the mesenchymal tissues and of the complex neural tube-notochord on the expression of adrenergic metabolism in neural crest. Zoon 6: 115-122.

Teitelman, G., H. Baker, T. H. Joh, and D. J. Reis (1979) Appearance of catecholamine-synthesizing enzymes during development of rat sympathetic nervous system: Possible role of tissue environment. Proc. Natl. Acad. Sci. U. S. A. 76: 509-513.

Zacchei, A. M. (1961) Lo sviluppo embrionale della quaglia giapponese (Coturnix coturnix japonica T.S.) Arch. Ital. Anat. Embriol. 66: 36-62.

Ziller, C., J. Smith, M. Fauquet, and N. M. Le Douarin (1979) Environmentally directed nerve cell differentiation: In vivo and in vitro studies. Prog. Brain Res. 51: 59-74. 